\title{
OBSOLESCENCE AND INNOVATION IN THE AGE OF THE DIGITAL Kathleen Fitzpatrick
}

Obsolescence and innovation are inextricably locked together, but their logic is not dialectical. While neither term can exist without the other, they are not delicately, viciously balanced opposites. Their logic is instead lenticular, two ways of looking at exactly the same thing. They are not just mutually imbricated, but identical; not just cut from the same cloth, but two angles on exactly the same fabric. Attempting to look at each independently winds up surfacing the other in the very act of definition. Even more, attempting to look at both together produces neither synthesis nor eternal tension, but rather a kind of eversion, a turning inside-out of our assumptions about the relationship between old and new. Perhaps this eversion is symptomatic of the contemporary-in-general: it is only in the present (any present) that our relationship to past and future matters enough to uncover the complexities of their relationship. But perhaps there is something specific about the period since 1945 that gives us, on the one hand, a future-oriented perspective that shapes the coming past, and on the other, an experience of the past that will linger long into the future. Like a character in William Gibson's Bigend trilogy, we inhabit the immediate future, 20 seconds ahead of the leading edge of the now. Like a character in Octavia Butler's Parable series, we find ourselves balanced in the coming aftermath of apocalypse, caught in a now that is made of nothing but change. The hinge between obsolescence and innovation is the nexus point of that now. We innovate through obsolescence; we ourselves obsolesce as we innovate. We create and are haunted by new and old alike.

Obsolescence may itself have been the defining innovation of the twentieth century. Giles Slade argues in Made to Break:

Deliberate obsolescence in all its forms - technological, psychological, or plannedis a uniquely American invention ... we invented the very concept of disposability itself, as a necessary precursor to our rejection of tradition and our promotion of progress and change.

(Slade 2006: 3) 
Intended to promote progress in the specific form of economic development during and after the Great Depression, the notion of obsolescence in its many forms (ranging from design obsolescence, in which small regular flourishes make old models less desirable, to death-dating, in which objects are given fixed life spans at the moment of their creation) drives innovation as well as the act of consumption that links the two. Making things old paves the way for the new, but it also leaves us with the persistent detritus of past innovation.

Obsolescence is therefore not a figure for the ongoing transformation of future into past, but instead demonstrates the eternal simultaneity of the two. The scandal of obsolescence lies in the effects of this simultaneity, which does not result in the evanescence of the material form of the obsolete object, or even necessarily of its usability, but rather in the waning of its value to us, its cultural cachet. Set aside, for the moment, the peculiar case of the outdated object that is prized for that very quality (the antique, the retro); in obsolescence, the object endures while our desire for it disappears. As John Durham Peters argues, it is this persistence that defines obsolescence; the obsolete object haunts us, ever-present but unused (2015: 90). Obsolescence is in this sense less a quality of things than a quality of our relationship to those things. Obsolescence and innovation are, most literally, ideological; they are ways of thinking about the world around us that often operate invisibly, as mere common sense, and yet they have far-reaching ramifications for the objects that surround us - not to mention for ourselves.

In fact, there is a question to be raised about the relationship between our ideas about the obsolescence of things and our own eternal sense of belatedness, as many of us find ourselves having increasing difficulty, across the span of our lives, keeping up with the now. Though this sense of belatedness contains within it the inescapable, material facts of our aging, our slowing, our approaching death, it is nonetheless manufactured, like obsolescence/innovation itself, through a process that is overwhelmingly ideological. Obsolescence, as Slade details, is far from a natural phenomenon; it was rather invented as a designed component of the product lifecycle, intended to spur consumption not just through the production of the new but through the manufacture of oldness. Obsolescence is thus not simply a reminder of, but the actual production of, our sense of belatedness. Our experience of the now-the fleeting, with which one must rush to keep up-is thus similarly manufactured and marketed.

Innovation, in this sense, is both the means through which we attempt to outpace the now, trying fruitlessly to propel ourselves out of the present and into the future, and the process through which we generate the past that encroaches ever more closely.

The ramifications of obsolescence and innovation for ourselves and our things are unpredictable, and at times paradoxical, in their effect; the obsolete object can lose all value and, as Vance Packard and Giles Slade reveal, become part of the ever-growing landfill on which we increasingly build our culture - or it can transform into a collector's object, even a fetish. Vinyl records form a small portion of overall record industry revenues, and yet those sales are not merely persistent but growing - up 52 percent in 2015 over the prior year, according to a report from the RIAA (see Cox 2015). Moreover, as Gabe Bullard explores in "Restoration Hardware," a cottage industry has sprung up, focused on the repair of curiosities such as manual typewriters, hi-fi stereo systems, and the iconic Polaroid camera. We might ask ourselves what qualities promote a particular obsolete thing for rescue from the landfill, but we should also consider what in us desires the selective transformation of the old into the vintage. What combination of aesthetics and nostalgia results in the hipster's recuperation of the purposefully out-of-date?

Perhaps there is something in the fact that much of the contemporary play of obsolescence/innovation locates itself around our communication technologies. This is an area in which the forces of innovation that, depending on one's angle, either create obsolescence 
or are propelled by it, seem dominant. We are abandoning our land lines, cutting our cables, moving toward an always-on mode of wireless communication that permeates the very air we breathe. Our devices (see the mobile phone, the tablet, the smart watch) become smaller, and then larger, and then smaller again; they take on dimension, and then flatten; they converge into one all-powerful device, and then disambiguate into specialized devices; they are attached to us metaphorically, and then very physically. With each innovation in function or design, the devices we already own - though it is often those devices that literally have us under contract-become obsolete: they may still be of the same use, but are no longer of the same value. Whether all of these relentless upgrades (some of which, on the software side, demand further updates to our hardware, a situation those Depression-era economists would have adored) have actually affected our ability to communicate with one another remains, however, something of an open question. They have undoubtedly transformed our experience of the act of communication, and thus our lived sense of what it is to communicate. If there is some social relation that is being transformed by our communication technologies, then it may be in that common experience: in connecting to our connected devices, we achieve an odd state of connectedness precisely by isolating ourselves, separately wireless-ed together.

However, it is not just our devices that reflect the constant churn of innovation and obsolescence as we seek the newest, fastest mode of connection. This pattern extends itself to the platforms on which we communicate, including both our software and social networks. Systems come and go: AOL, Friendster, and Geocities now strike us as hilariously dated. But even the systems we continue to use are subject to this process. Email, Facebook, and other such systems once seemed so new and exciting to us; not only have many become sources of obligation, anxiety, work (a transition mapped as early as 2005 by the Pew Internet and American Life project), but they have also gathered painful generational associations. As Bob Lefsetz points out, "Facebook is for old people": "Documenting your entire life history, building a timeline, a shrine to yourself, so that the people you grew up with will be impressed? That's for baby boomers"; the kids today gravitate toward more immediate communication about the now (2013). The obsolescence of a system, in other words, may not be entirely tied to its disuse; it may have just as much to do with who uses it and how. In that sense, Snapchat is emblematic, both for its imperfect evanescence- the photo sent from a wireless device, meant to self-destruct in 30 seconds, but which can nonetheless be captured, disseminated, and preserved in unintended ways - and for the media narratives of its quick adoption by the young, with perfect bafflement of the old. It is possible, as Wendy Chun (2008) has suggested, that we are driven by the desire for our communication processes to take place at the speed of experience, as a hedge of sorts against our own belatedness.

Perhaps that hedge is at the root of all of our attempts to manage time, from productivity porn to slow food. In the recuperative drives of hipster culture, from 80s-era (and now, increasingly, 90s-era) fashion to fixed-gear bikes and artisanal crafts, there is the longing for a greater permanence, not just for things, but also for the self. Value is carefully crafted not just around the new, but also around the innovative rebirth of the old. What is desired in that oldness is often the signs of care that arise from use, from the patina of age; much less esteemed, but still salable, as Hanjo Berressem explores in the work of William Gibson, are manufactured versions of patina. Recent stories suggest, for instance, that there is a perverse kind of status accorded by some teens to having a cell phone with a cracked screen, to such an extent that developers are cashing in with wallpapers mimicking the effects of such brokenness. See Wax: 
[S]ome young people say a cracked screen gives you a sort of street cred, like you've been through some real-life stuff, even if it happened on the mean streets of Bethesda. It's tough, subversive and just kinda cool.

(Wax 2013)

In all of this, we find a deep tension between the consumer's desire for the new and the consumer's resentment at being required to let go of the old-between the corporate seductions of innovation and the equally powerful reincorporation of consumer resistance through the innovative use of obsolescence.

Pursuing a full elaboration of an analysis such as the one I am attempting here requires something of the standpoint of the neutral observer, one who can sufficiently understand our new technologies and platforms without fully adopting, or being adopted by, them-one who can stand at enough of a remove from the machinations of capital to study them without getting caught. This, suffice it to say, is not a position I can inhabit-but then, I am not sure that it is a terribly habitable position at all in the early twenty-first century. As scholars, and particularly scholars in the critical tradition of the humanities, we rely on our ability to resist the relentless propulsion of our culture into the future, on our training, which leads us to linger, to proceed with great deliberateness, and to keep open the avenues to the past. We rely, that is to say, on our ability to think through the present moment. And yet our experiences, and our work, are as mediated by our relationships with our communication technologies as anyone's.

We need to think, as scholars, that we can think through, that our thought takes place outside the dynamics of neoliberalism that drive so much of the contemporary relationship to the lived world. We embrace a lifestyle that is deliberate, that understands history, that requires careful contemplation. We are slow to discard the past and cautious about the havoc that innovation may wreak on our ways of working. We try to reconcile past and future-in all ways except in the development of our ideas. There, we follow a path of innovation through obsolescence that is every bit as ruthless as that emerging from factories and boardrooms. This mode of critical production may have its most literal manifestation in the "they say/I say" mode of understanding academic writing popularized by Gerald Graff and Cathy Birkenstein. Certainly laying this form of argumentation bare can help us develop fluency in the dominant moves espoused by academic discourse, but it perpetuates a reductive mode in which the author summarizes and dismisses prior arguments rather than genuinely engaging with them. And as in specific arguments, so in the academy at large: a new idea, or a new field, emerges on the scene; it does battle against the status quo and gathers critical or institutional support; for a shockingly brief moment, it may even achieve some kind of success. Then, in a flash, it either dissolves into the quaintly retrograde or, at best, becomes the status quo against which battle is done, in which case it gathers a next generation of critics arguing against it. The new idea is inevitably consigned to the passé, the reductive, the reactionary, and the old. Very, very few scholarly ideas escape this cycle, and those that do often become so naturalized in academic discourse that their references disappear, becoming indistinguishable from common sense. Some once-discarded ideas get recovered from the ash-heap of the scholarly past to have new life breathed into them, but they are a precious few, and it is the re-reading, the recuperation, that gives them their new value. In this sense, the renewal of critical interest in the work of a figure such as Herbert Marcuse (on which, see Romano 2011; Parry 2013) is not all that different from listening to vinyl LPs or writing with manual typewriters. 
If the paired terms obsolescence and innovation represent not just the lenticular logic of consumer culture, but also the lenticular logic of cultural criticism, we might begin to recognize another reason why, as Bruno Latour (2004) has asked, critique has "run out of steam"- not simply because we have been undermined by our own resistance to the notion of the unconstructed fact, but because critique as a mode of discourse necessarily generates its own obsolescence. We as scholars obsolesce not because we fail to innovate, but because critique's negativity means that we cannot help but innovate at our own expense. One might ask whether, and how, we can develop the more positive critique Latour calls for, a critique that is fundamentally about care, a critique that might value building upon the past more than rejecting it in favor of the future.

Perhaps such a reorientation of critique might find its bearings in seeking out a mode of more direct, ongoing engagement with one another, and even with a set of broader publics, that modulates the iterative innovation-through-rejection mode of scholarly discourse and instead places multiple perspectives into ongoing conversation. Conversation, in fact, may be one avenue through which we could find our way past the need to do battle with one another-to see new ideas and old in an endless cycle of Oedipean combat-allowing us instead to create a space within which we can keep critique alive and renewed precisely by keeping old and new in active dialogue.

If we are to build such critical conversation, we must think carefully about our uses of the increasing range of technologies of inscription and dissemination that we have for connecting with one another, and for reaching out to other engaged publics. Certain of our technologies - the book, most particularly — seem to demand both a relentless production of critical innovation (in order for a publisher to be willing to invest in its dissemination) and an equally relentless resistance to future conversational forays (in the form of the text's finality, fixity, and closure, all of which leave it un-updatable, death-dated, and inevitably obsolete). Others of our technologies - at the moment, one might place Twitter in this category, though I am acutely aware of the ways that reference will inevitably date this very argument-create a flow so relentless that one is never quite able to catch up, unable even to sustain the fantasy of returning to the archive and rereading the conversation as it unfolded. Somewhere between the book's orientation toward the past and Twitter's relentless propulsion into the future might lie a platform-which, having come of age in the academy and the digital environment of the early 2000s, I cannot help but associate with the blog-that looks both forward and backward, that allows for an immediacy closer to that of conversation but that extends those conversations both temporally and across the networked landscape, that permits multiple voices engaged in revisiting and rethinking questions that have already been asked as well as raising new questions in a timely fashion, that keeps the now front and center while producing its own powerfully interconnected, always-available archive. (It is, of course, impossible to escape the irony in treating a platform as relatively new as the blog as a form in which we might achieve some kind of stability for the critical present. However, though the blog's obsolescence has been repeatedly pronounced over the last decade, its structures nonetheless underwrite a growing percentage of the web. The blog has become something more than itself-no longer merely a genre, but instead an engine, and one whose survival and expansion are worth paying some attention.)

We must pay careful attention to the platforms on which we stage our critical conversations, not least because of who we become when we engage with and on them. As Lisa Gitelman notes, "changes to writing and reading matter in large measure because they equal changes to writers and readers. New inscriptions signal new subjectivities" (1999: 11). The conventional wisdom unsurprisingly suggests that, the more we engage with writing and 
reading on new, malleable digital platforms - the more our practices of inscription give the appearance of dematerializing - the more oriented toward the ephemeral our own subjectivities become. Moreover, it would appear that we struggle with reading deeply today, as we are repeatedly exhorted to recuperate the value of slow engagements with writing in a culture that privileges speed (see Tombolini n.d.). However, as Matt Kirschenbaum's work on media forensics and the materiality of digital text might remind us, there is an extraordinary persistence to the digital, even in the midst of its malleability. Exploring the actual functioning of our inscriptive technologies - rather than the ways the technologies represent themselves as functioning, or the ways their promoters or detractors represent them-is crucial to understanding the ways that we will be able to make use of them in our own critical practices. As Kirschenbaum argues,

electronic textual theory has labored under . . . uncritical absorptions of the medium's self- or seemingly self-evident representations. While often precisely Romantic in their celebration of the fragile half-life of the digital, the "ideology" I want to delineate below is perhaps better thought of as medial - that is, one that substitutes popular representations of a medium, socially constructed and culturally activated to perform specific kinds of work, for a more comprehensive treatment of the material particulars of a given technology.

(Kirschenbaum 2008: 36)

Those popular representations are, in no small part, elements of the same kinds of marketing that have centralized the processes of obsolescence and innovation in contemporary media culture, not to mention contemporary critical culture. If we have adopted those representations as ways to describe our lived experiences of technology, then they only reveal the extent to which that lived experience is one which, like the technology itself, we have been sold.

Not everything new is created to be sold, of course, just as not everything old is destined to become waste or fetish. But our ways of understanding newness and oldness, speed and deliberation, ephemerality and permanence in contemporary culture are inevitably shaped by the ideological processes of obsolescence and innovation that privilege those modes of engagement with things. However much obsolescence urges us to dispose of the old and innovation presses us to buy the new, their lenticular logic reveals the extent to which each creates the other, creating a temporal paradox of sorts in which our future brings our past into being, and our past becomes the detritus of that future.

This is no less true of ideas than it is of things. It is possible that the only truly productive critical possibility is to acknowledge the force that obsolescence and innovation have in our own work, seeking some position of care within the now that requires neither a relentless pursuit of the new nor a retrenchment in defense of (or a recuperation of) the old. Whether such a position is possible-or whether it requires stopping time itself-remains to be seen.

\section{Further Reading}

Packard, V. (2011) The Waste Makers, Brooklyn, NY: Ig Publishing.

Slade, G. (2006) Made to Break: Technology and Obsolescence in America, Cambridge, MA: Harvard University Press. Strasser, S. (1999) Waste and Want: A Social History of Trash, New York, NY: Henry Holt.

Thill, B. (2015) Waste, New York, NY: Bloomsbury.

Tischleder, B. and S. Wasserman (eds.) (2015) Cultures of Obsolescence: History, Materiality, and the Digital Age. New York, NY: Palgrave Macmillan. 


\section{References}

Berressem, H. (2015) “'Zero History': The Poetics of Patination in the Work of William Gibson,” in B. B. Tischleder \& S. Wasserman (eds.) Cultures of Obsolescence: History, Materiality, and the Digital Age, New York, NY: Palgrave Macmillan, pp. 173-89.

Bullard, G. (2013) "Restoration Hardware," The Magazine 18.

Chun, W. H. K. (2008) “The Enduring Ephemeral, or the Future Is a Memory," Critical Inquiry 35(1), $148-71$.

Cox, J. (2015) "Vinyl Sales Are More Valuable than Ad-supported Streaming in 2015," The Verge, retrieved from www.theverge.com/2015/9/28/9408233/vinyl-sales-ad-supported-streaming-riaa-2015-report.

Gitelman, L. (1999) Scripts, Grooves, and Writing Machines: Representing Technology in the Edison Era, Stanford, CA: Stanford University Press.

Graff, G. and C. Birkenstein (2010) They Say / I Say: The Moves that Matter in Academic Writing, New York, NY: W.W. Norton \& Co.

Kirschenbaum, M. G. (2008) Mechanisms: New Media and the Forensic Imagination, Cambridge, MA: MIT Press.

Latour, B. (2004) "Why Has Critique Run out of Steam? From Matters of Fact to Matters of Concern," Critical Inquiry 30(2), 225-48.

Lefsetz, B. (2013) "Facebook Is for Old People," Lefsetz Letter, retrieved from lefsetz.com/wordpress/index.php/ archives/2013/06/02/facebook-is-for-old-people/.

Lenhart, A., M. Madden, and P. Hitlin (2005) Teens and Technology, Washington, DC: Pew Internet and American Life Project.

Packard, V. (2011) The Waste Makers, Brooklyn, NY: Ig Publishing.

Parry, M. (2013) "Newly Discovered Draft of Marcuse Book Reveals Turn toward Pessimism," The Chronicle of Higher Education, retrieved from chronicle.com/article/Newfound-Early-Draft-of/141949/.

Peters, J. D. (2015) "Proliferation and Obsolescence of the Historical Record in the Digital Era," in B. B. Tischleder and S. Wasserman (eds.) Cultures of Obsolescence: History, Materiality, and the Digital Age, New York, NY: Palgrave Macmillan, pp. 79-96.

Romano, C. (2011) “Occupy This: Is It Comeback Time for Herbert Marcuse?” The Chronicle of Higher Education, retrieved from chronicle.com/article/Occupy-This-Is-It-Comeback/130028/.

Slade, G. (2006) Made to Break: Technology and Obsolescence in America, Cambridge, MA: Harvard University Press.

Tombolini, A. (n.d.) Slow Reading Manifesto, retrieved from www.slowreading.org/.

Wax, E. (2013) “Beat-up Cellphones with Cracked Screens Are Point of Pride for Some Young People," Washington Post, retrieved from articles.washingtonpost.com/2013-05-17/lifestyle/39333160_1_screen-iphone-lofton. 